\title{
The Factors that Affect Toward Performance and Cooperative Success
}

\author{
Siti Maria \\ Management, Faculty of Economics and Business, \\ Mulawarman University, Indonesia
}

Dio Caisar Darma

Management,

Samarinda High College of Economics Science, Indonesia

\author{
Mursidah Nurfadillah \\ Management, Faculty of School of Economics, Law, Politics and Psychology, \\ Muhammadiyah University of East Kalimantan, Indonesia
}

\begin{abstract}
Performance of management in cooperatives is crucial in order to improve prosperity. Performance management is not only measured by the success of the business but also the ability to improve the welfare of members. Performance as a result of business activity does not stand alone but by several factors. Qualities of management, member participation, support employees, the environment are examples of factors that affect the performance and success of cooperatives. The failure of cooperatives often occur due to the quality of management is weak, the participation of members less, support employees who are weak and environmentally counter- productive. Therefore, there needs to be a synergy between the various factors that increase the performance of the cooperative board.
\end{abstract}

Keywords: Factors; Management; Performance; Success

\section{INTRODUCTION}

Investigating the success factors of Poultry Growers' Cooperatives in Iran identified active member participation in the administration of cooperatives as a key factor influencing the successful performance of cooperatives [2].

Cooperatives in the community, on the one hand, are still often aligned with inefficient business activities, because they emphasize more social aspects (social oriented), while on the other hand it can be considered an efficient business activity because it is profit oriented. The difference in this conception is due to the fundamental differences in occupying cooperatives as business entities. Cooperative understanding can use three approaches, namely normative, legalistic, and positive. Based on normative, cooperative is a spirit that provides cooperative decision instructions. Legalistic states that cooperatives are business entities that have legal entity status [3]. The positivism sees cooperatives as business entities that are inseparable from economic rules.

The performance of cooperatives is affected by several factors. For instance Vander Walt through a research on failed cooperatives in Africa indicated that the debility of management, lack of education, the conflict between members and lack of capital were the most important factors affecting cooperative's failure. Van Niekerk considered the debility of management as the most important reason for failure of cooperatives. In a review about fishing cooperatives in 
Turkey concluded that the management skills is one of the internal factors affecting on these companies's success [25].

There are several contributing factors that lead to cooperatives' performance. Strategic planning, members' participation, human capital, structural and relational capital are among the identified factors by past literatures. Past and present literatures agree that strategic planning is one of the factors contribute towards firms' performance. Strategic planning is a process of carrying out the firms' mission, vision, objectives and goals of the organisation. Every board of directors must understand the strategic planning they have in their organisation to ensure that their business runs, moves toward achieving their objectives. A survey conducted among the 200 general managers and board presidents of agricultural cooperatives in Minnesota and Wisconsin reported that all Board agreed that cooperative should had well defined missions, objectives and goals but disagreed that their cooperative had a well developed and written strategic planning [26].

Past study had found a positive significant influence of the strategic planning on cooperatives' performances. This is supported by a tentative framework developed in study conducted that having a long term plan for cooperative will influence the performance of cooperatives in Malaysia [15]. Moreover, a study conducted among the 250 board of directors of cooperatives in Malaysia also reveals that cooperative that has a strategic plan for at least 3 years significantly contribute towards the success of cooperatives [16]. On the other hand, [4] in their study of 113 UK companies found that there is no relationship between strategic planning and company performance. The importance of strategic planning in cooperatives cannot be denied as [13] in a study conducted in Fiji on factors contributing towards cooperatives' successful performance demonstrated the main reason that cooperatives were unsuccessful in Fiji was due to inadequate planning. Therefore, these studies incorporate strategic planning as one of the important factors to determine cooperatives performance.

\section{Figure 1. Cooperative Organization as a Socio-Economic System}

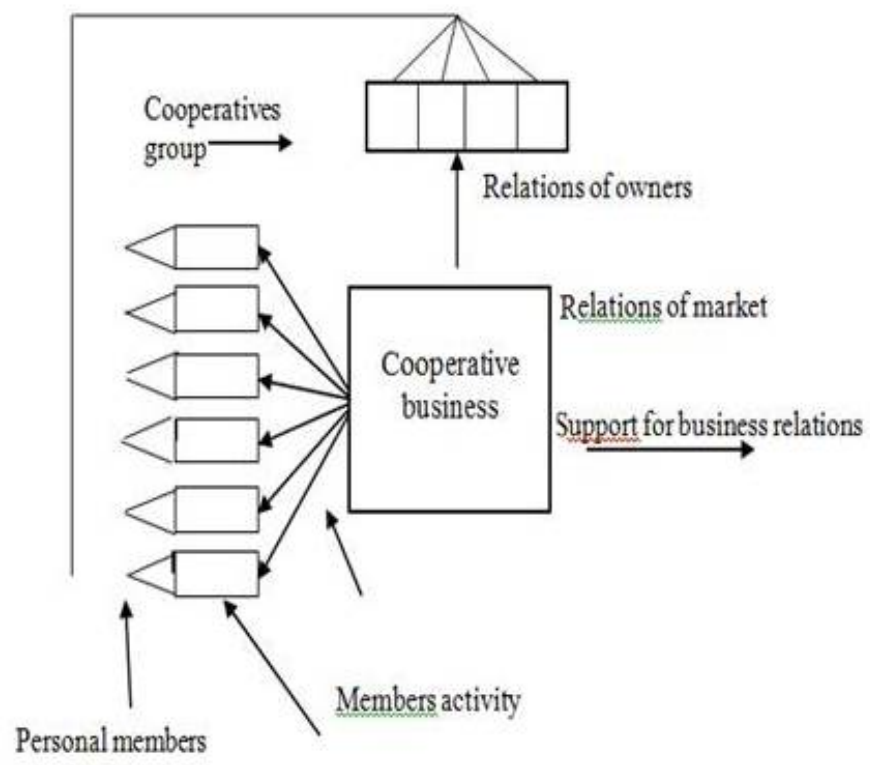

In accordance with these three approaches, cooperatives are an organizational method for carrying out a business by members democratically. Cooperatives are a joint effort to improve the fate of economic livelihoods based on help. Cooperatives as an association of people, who join voluntarily to realize a common goal through the formation of a democratically supervised 
organization by giving the same contribution as much as the amount needed, participating in taking the appropriate risks to obtain benefits from the business where the members play an active role [7].

The two cooperative constraints mentioned above give the meaning that cooperatives are a collection of people who aim to improve their fate based on help. Perfect cooperative boundaries are difficult to obtain because at each boundary stated has different emphases, but has the same meaning. On that basis, the cooperative needs to be reviewed based on the aspects of the prevailing socio-economic system.

Based on the socio-economic system, cooperatives have elements of cooperative organizations, namely: individual members, economic activities of members, who are household, and corporate, cooperative groups, and cooperative companies. There are four elements as a socioeconomic system. Ownership relationships with cooperative companies and supporting business relationships. Supporting relationships are relationships that are capable of increasing members' economic activities.

\section{Cooperative Management}

\section{CONCEPT DEVELOPMENT}

The composition of the Cooperative Management is based on the provisions [3] concerning Cooperative, the composition of the management consists of the chairman, secretary, and treasurer who have their respective duties.

\section{Figure 2. Cooperative Organizational Structure}

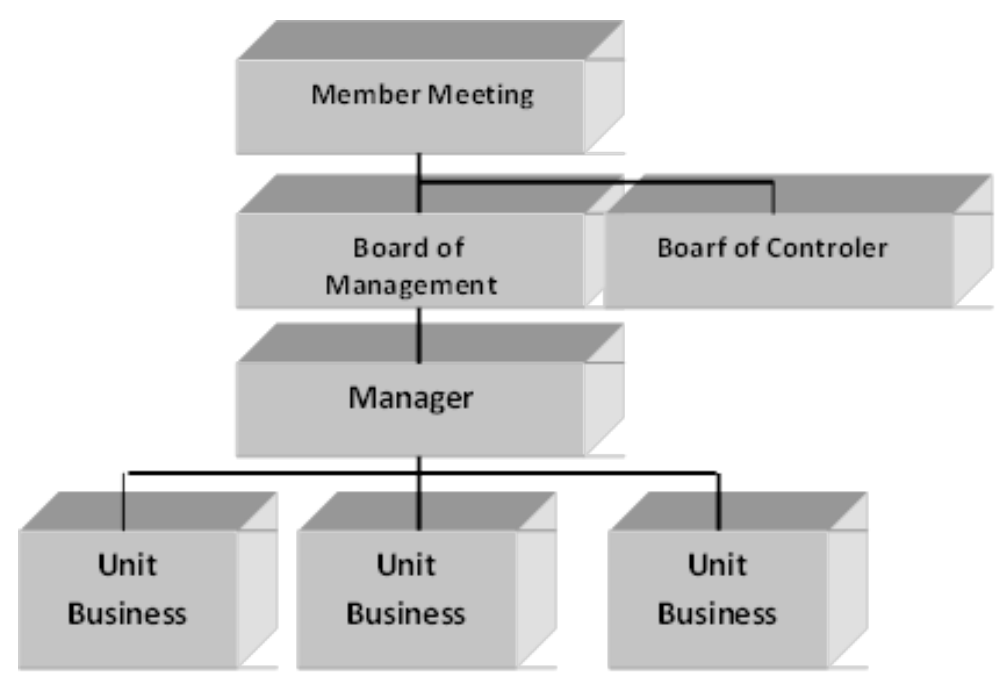

The organizational structure is an embodiment that shows the relationship between functions and authorities and responsibilities that relate to one another from people who are given the task or responsibility for the function in question [24]. An organization as an activity is actually a working mechanism of management. This means determining the design of the parts that must exist to support the work of an organization, or in other words, the organizational structure is a comprehensive framework that connects functions with one another, so as to form a system [19].

The organizational structure of cooperatives in Indonesia is governed concerning cooperatives [3]. Meeting members as the highest authority has the right to choose, appoint or dismiss the management and supervisor. Administrators and supervisors in carrying out their functions are responsible for meeting members. The manager is a special staff who has the skills and 
abilities in the field of business, appointed and dismissed by the management by referring to the meeting of members to lead a cooperative effort. The manager in carrying out his duties is responsible for the management. Managers have the authority to appoint and dismiss cooperative employees. The position of employees in the cooperative organizational structure is to provide operational services to members.

The provisions of the meeting of members, administrators, supervisors, and managers are regulated [3]. Meetings of primary members are regulated in articles 22 to 28, managers are regulated in articles 29 to 37. Supervisors are regulated in articles 38 to 40. Provisions concerning the management of cooperatives are regulated in the authority of the management of article 32 .

Members' meetings determine: Articles of Association, general policies in the field of organization, selection, appointment, dismissal of Managers and Supervisors, work plans, cooperative income and expenditure budget plans and financial statement ratification, ratification of the management's responsibilities in carrying out their duties, the distribution of the remaining proceeds of the business, and the merger, consolidation, distribution and dissolution of the cooperative.

Decisions of member meetings are taken based on deliberation to reach consensus. If no decision is reached by deliberation, then the decision is made based on the majority of votes. In the case of voting, each member has one vote. Meeting of members has the right to ask for information and accountability of Managers and Supervisors regarding the management of cooperatives. Member meetings are arranged as follows:

○ Member meetings are held very little in one year;

- Member meetings to certify accountability of management is held no later than six months after the past financial year;

- An extraordinary meeting of members is carried out if the situation requires an immediate decision whose authority is at the meeting of members;

- An extraordinary meeting of members is held at the request of a number of members or the decision of the board whose implementation is regulated in the Articles of Association;

- Meetings of extraordinary members have the same authority as the authority of member meetings as referred to in point 2;

- Requirements, procedures and place for holding member meetings and extraordinary member meetings are regulated in the Articles of Association.

The provisions of the cooperative management regulated is as follows [3]:

$\circ$ The management is elected from and by the members of the cooperative at a member meeting;

- The management is the power of attorney for member meetings;

- For the first time, the composition and names of the members of the management are included in the deed of establishment;

- The term of office of the board is a maximum of five years;

- Requirements to be elected and appointed as management members are stipulated in the Articles of Association.

The duties and authority of the management are as follows:

$\circ$ The management is in charge of: managing the cooperative and its business, submitting a draft work plan and draft plan of the cooperative's income and expenditure budget, 
holding a member meeting, submitting financial reports and accountability for the implementation of tasks, and maintain a list of books of members and administrators;

- The management is authorized: to represent the cooperative inside and outside the court, decide on the acceptance and rejection of members in accordance with the provisions in the Articles of Association, take actions and efforts for the interests and benefits of the cooperative in accordance with their responsibilities and decision of the meeting of members;

- The management is responsible for all cooperative management activities and their efforts at member meetings or extraordinary member meetings;

- Management of the cooperative can appoint managers who are given authority and power to manage the business;

- In the event that the management of the cooperative intends to appoint a manager, the appointment plan is submitted at a member meeting for approval;

- Managers both together and individually bear the losses suffered by the cooperative because the actions carried out with intentional or wrongdoing;

- In addition to the compensation, if the action is carried out intentionally, it is possible for the public prosecutor to prosecute;

- After the cooperative's financial year is closed, no later than one month before the annual membership meeting is held, the Management prepares an annual report containing at least: an annual calculation consisting of the balance sheet at the end of the financial year.

\section{Performance of Cooperative Management}

Humans are essentially social beings who have a tendency to live in groups or in society. As social beings, it means that humans are interdependent with other humans [20]. The statement gives the meaning that in humans in maintaining their lives cannot be done alone, but requires other people who have goals that are relatively the same.

On the basis of consideration of the inability to live alone, humans form organized groups, ranging from the simple to the complex. Each organization has a basis for grouping, such as people, capital, background, goals or a combination of several basic references. The basis of grouping on cooperatives is individual persons and cooperative legal entities that have the purpose of increasing their welfare.

The management performance is basically a result or workability that can be achieved by the management of the cooperative in accordance with the authority and responsibility in management. Ability is a born and learned attitude that allows a person to finish a job [1]. Performance is the record of outcomes produced on a specified job function or activity during a specified time period [27].

The form of management performance is the ability to make and implement management functions, such as planning, organizing, directing, coordinating, and supervising. The same opinion about management functions proposed [20] management is the process of planning, organizing, directing, and supervising the efforts of members of the organization and the use of other organizational resources to achieve the goals set.

Planning is an estimate of the future that is based on reasonable expectations [17]. The main consideration in making plans is the interests of members. Managers must be able to plan for the future through cooperative efforts in accordance with the wishes of the members delivered through member meetings. 
Planning is careful thinking to consider, determine and regulate the factors needed in running the company [12]. The organizing function is related to the process of creating relationships between personnel functions and physical factors so that activities can be integrated with achieving goals, or in other words per person is a process of creating interrelated functions of relations so as to create synergies that support the achievement of goals. Organizing a cooperative is related to a clear organizational structure, thus facilitating a clear division of labor among organizational functions.

The directing function of a cooperative is a management function that directs the activities of organizational functions carried out by the management. The purpose of direction is for all activities to be in accordance with their functions and responsibilities. The function of direction in cooperatives involves several personnel groups, such as administrators, supervisors, members, and employees. The coordination function is related to efforts to integrate activities from various implementing groups so that they are directed towards achieving goals. Coordination in cooperatives can be held in formal or non-formal meetings. In terms of coordination, administrators should be open and pro-active in communicating with fellow management members, supervisors, members, and employees.

Supervision is an activity to provide an assessment of a work that has been done. The purpose of this oversight is to avoid activities that deviate from the original objectives. The principle of supervision in cooperatives must be economical, flexible and easy to understand, so as to be able to cause corrections to deviations from activities that occur in cooperatives [17]. Supervision of cooperatives is generally carried out by administrators and supervisors. On that basis, the relationship between management and supervisors must be truly cooperative so that it supports the achievement of goals.

Administrators and supervisors have the same task of fostering and developing cooperatives in only different functions. The working principle of administrators and supervisors is: recognizing and realizing that their role is to serve members of cooperatives and the community, pay attention to the difficulties and problems that arise in cooperatives and try to find solutions, maintaining harmony and increasing member participation in cooperative life, cooperating with managers and employees in the framework of fostering and developing cooperatives, and not trying to obtain personal benefits by harming cooperatives, avoid all forms of abuse of power and authority for personal gain, disclose the facts to a member meeting when his personal interests are involved with cooperative efforts, recognize and realize that members have the right to obtain information about cooperative business activities, the supervisor is obliged to carry out of the examination and report the results of the examination to the member meeting.

\section{The Success of Cooperatives}

The main task of the cooperative management is to provide satisfactory services to members. The success of cooperatives can be seen from cooperative effects that are accepted by members [29]. The high and low cooperative effect depends on the performance of cooperative management. Effective and efficient management performance can be done through structuring the patterns of working relations of the management in cooperative organizations. Cooperative managers need to pay attention to the interests of members and parties relating to activities carried out by cooperatives, such as employees, customers, partners, and the community [6]. 
The motive (impetus) that underlies the formation and incorporation into cooperative organizations is to enjoy the greatest possible economic benefits for companies, farms, and households by creating and utilizing the cooperatives' tools for their usefulness [11]. If the incentives (benefits) provided by cooperatives are greater than other organizations or markets, then someone decides to become a member of the cooperative, and vice versa he comes out if the benefits received by members are found to be lower. Such actions are reasonable because someone in making a decision is rational. The growth of cooperative companies can be achieved through: the growth of the economic activities of its members, increasing the intensity of business relationships with its members, increasing the number of members, and increasing business with non-members. The success of the Village Unit Cooperative can be seen from various aspects, but the reality of the analysis of experts is more than emphasizes the economic aspects than non-economics [7].

The expectations of members towards cooperatives are satisfying services in meeting their needs. If a cooperative provides a higher level of satisfaction to someone than other organizations, this means that the cooperative has a higher ability to satisfy the desires of the person [8].

Common services provided by cooperatives include low costs as a result of low transaction costs. Another factor that can reduce costs for cooperatives is the low transaction costs. If the transaction costs are low, then the price of commodities or products received by members becomes low [14].

The risk of uncertainty in cooperatives is lower without sacrificing the freedom of members as producers or consumers [8]. This means that the cooperative provides a guarantee to members for the availability of products or commodities needed. Based on these descriptions the success of cooperatives can be seen from low transaction costs, low commodity/product prices, and the availability of commodities/products more assured. Some experts have argued that the success of cooperatives can be seen from the remaining results of the business obtained.

The position of members as owners and customers has implications for their rights and obligations. The position of a member is characterized by his dual skills as a member of a cooperative association and service users provided by a cooperative business entity [11]. Members through the meeting of members make the formulation of objectives that are in accordance with the interests so that at the operational level members do not face complicated procedures in utilizing cooperative services. The success of cooperatives can also be seen based on the amount of residual income enjoyed by members. The amount of the remaining results of the business depends on two things, namely the amount of the remaining results of the business as a whole, and the amount of the contribution of members to the cooperative. The greater the contribution of members to cooperatives, the greater the remaining operating results received by members.

\section{Successful Cooperative Group}

Organizational behavior can be distinguished based on decision-making behavior. Distinguish six human models of management decision makers [20], namely: human economic models, human models of administration, mobricent human models, organizational human models, human models of entrepreneurs, and social human models. The human economic model emphasizes that a person's rational decision to achieve marginal income with marginal costs, so as to obtain maximum profits. The human model of administration emphasizes that a person does not want to maximize, but a satisfying advantage. The mobricent model emphasizes change as the main value, so people always move to make decisions. The human 
model of the organization has the nature of being loyal and full of cooperation in making decisions. The entrepreneur's human model is always competitive, and social humans emphasize things that are irrational in making decisions, always overwhelmed by feelings, emotions, and situations in the unconscious.

The realization of this decision-making behavior model does not stand alone in extreme ways, but is a combination of these models. A management decision maker may have more than one behavior model. Decision-making behavior in cooperatives seems to be closer to administrative, mobility, organizational, and social models. The economic and entrepreneurial behavior model is considered to be less profitable for the development of cooperatives because profit maximization and competition will occur to the detriment of members' interests.

Organizational behavior into three types, namely: task-oriented behavior, group-oriented behavior, and personal-oriented behavior. Task-oriented behavior includes behaviors that help groups, choose and advance the achievement of goals. Group-oriented behaviors include behaviors that help improve interpersonal relationships, and choose group relationships and resolve conflicts between members. Personal-oriented behavior is the action of people who only fulfill their personal needs. In general, personal oriented behavior in carrying out tasks often disrupts groups and impedes problem-solving, so this type is not suitable for cooperative development [28].

This review uses a behavioral model approach developed [28]. This model is very simple, making it easy to understand identifying management performance. The three reasons that underlie this model are used: Placing humans in the position of duty, namely behavior that pays attention to work tasks that are their responsibility, or in other words this behavior prioritizes tasks over personal interests, Placing humans in a group maintenance position, namely behavior that seeks to help groups to achieve group goals, Placing human beings in a personal position, namely behavior that prioritizes personal interests compared to tasks that are their responsibility.

Organizational behavior models that are relevant to the development objectives of the cooperative include the Village Unit Cooperative which is a task-oriented and groupmaintenance behavior model. Behavior that prioritizes personal interests is considered inaccurate because it contradicts the basic foundations of cooperatives that uphold common interests. On the basis of that, the cooperative management should be the person who prioritizes the task and maintenance of the group rather than his personal interests.

As already mentioned, the position of the cooperative board is central and strategic for the development of cooperatives. On the basis of that the success and failure of a cooperative rest on the workability of the board. The quality of leadership and the ability to manage are important for the development of successful cooperatives [11].

A harmonious and dynamic working relationship between the management and supervisors, members, employees, customers, partners, and the community is a manifestation of good management performance. Managers who are less able to make a good work climate in managing cooperatives can hinder cooperative development in the future [9].

The performance of the cooperative board can be seen in achieving the goals set. If the cooperative is able to achieve the stated goals, then the cooperative is declared successful (business success). The success of cooperatives can be reviewed based on two things, namely 
the success of the business and the success of the members. Financial analysis can be used to see the success of the cooperative business, while the success of members (member success) based on benefits received by members.

On the basis of the concept of success, cooperatives can be classified into four groups. First, cooperatives that succeed in business, also succeed in promoting members; Second, cooperative groups that succeed in business, but do not succeed in promoting members; Third, cooperatives that are not successful in business, but are successful in promoting members; Fourth, the group that did not succeed in the business also failed to promote members.

The ideal cooperative group is the first cooperative group, which is successful in advancing the business, also increasing the welfare of its members. The second group in the short term can still survive, but in the long term there is no member support, so the cooperative will dissolve. The third group is difficult to develop because cooperatives are faced with inefficient business conditions, so the costs used for operational services are limited, which in turn members receive limited services. The limited service received by members causes the support of members to be lost, so the existence of the cooperative itself is lost. The fourth group is a nameplate group cooperatives do not show management activities or activities.

\section{DISCUSSION}

\section{The Factors that Affect Toward Performance and Cooperative Success}

The aim of improving cooperative organizations is to improve the operational capabilities of each and every person in the organization, which in turn is reflected in the improvement of the overall organizational performance. The journey of a cooperative organization, at one time, may experience a situation that is not aligned due to the factors that influence it to change.

Managers as managers of cooperatives should avoid the form of situations that are not in harmony through anticipation of any changes that occur so that the changes that occur do not become an obstacle to the mechanism of work of the management. Two factors that influence the mechanism of management work, namely management philosophy, and environmental factors [22]. Management philosophy include: Management's attitude towards employees, Consumer provision, (3) Government; and (4) Members. Environmental factors include (1) Socio-economic conditions; (2) Education; Politics and legal certainty, and Culture. The factors that have a meaningful relationship with the management performance of the management and the success of the cooperative, among others, the quality of management, member participation, cooperative employee support, and the environment. These factors influence the management performance of the management and the success of the cooperative [9].

\section{Quality of Management}

The management is the holder of the mandate of the cooperative owner so that to realize the decision of the meeting members is required by the management who has certain qualifications. The quality of the management is the condition of the ability to carry out the cooperative management process. Administrators should be chosen from people who know a lot about the ins and outs of the business, and the intricacies of cooperative organizations [17]. Good management qualifications, among others, have the motivation to advance cooperatives, be wise, be friendly, honest, open, and able to work together, have a sufficient level of education, experience in organization, and operate [9].

Motivation is a condition in a person who encourages carrying out certain activities in order to achieve goals [20]. Motivation can be distinguished between internal and external motivation. Internal motivation is the encouragement or desire of someone who emerges from the 
individual concerned, while external motivation is caused by external factors, such as work atmosphere, salary, policy, and work relations.

A wise manager is an administrator who is able to encourage growing a person's initiative fairly, without sacrificing the interests of others. A friendly, honest and open attitude is needed for the cooperative management process that is based on democracy. Managers at all times will always relate to people as a consequence of the organization that brings people together, so that friendliness, honesty, and openness become absolute for the life of the cooperative. The absence of such attitudes will be an obstacle to cooperative development efforts.

The management does not work individually but is compact teamwork in carrying out management tasks. Management as teamwork requires the ability to work together, both with fellow members of the management and with other parties. In addition to the ability to work together, administrators should also have adequate levels of education and organizational experience. Education and experience can improve one's knowledge and skills. Included educational factors because through education the insights of management knowledge and skills became wider and had a mindset that could encourage the development of cooperatives $[11 ; 23]$.

Experience is basically an understanding of a work that is lived by someone so that they acquire knowledge, skills or attitudes that are integrated with the person concerned. The longer someone enters a job, the more experienced and skilled in managing work. More explicitly that professionalism and work skills increase with work experience. Education and experience change the cognitive, affective, and psychomotor structure of someone who experiences it, then determines behavior. Managers who are educated and experienced are expected to improve their ability (performance) to manage cooperatives [5].

The cooperative entrepreneur is a positive mental attitude in creative endeavors by taking innovative initiatives and the courage to take risks and cling to the principles of cooperative identity in realizing the fulfillment of real needs and increasing shared prosperity. The definition of Cooperative entrepreneur is more simply who are people who have the ability and willingness to innovate or get a strategy for the development of cooperatives [8]. The task of the entrepreneur is to condition the cooperative he leads in such a way that he is able to compete with the business organizations of his competitors or competitors.

\section{Participation of Cooperative Members}

The position of members as owners and customers (identity) means that members have the highest authority manifested in the form of meeting members. The management as the member of the member meeting mandate should respond responsibly to the trust given by the members. Member participation, both in the form of resources, decision making, and utilization is based on the trust of members. This is easy to understand, because the position of the members of the cooperative is the principal, while the management is the agent so that in such situations there is an opportunity for moral hazard to emerge from the agent. On this basis, the moral hazard that might occur to the management should be avoided by an open attitude in managing the cooperative.

Moral hazard can be avoided by maintaining productive relationships between administrators and members. Positive intentions from the management need to be realized in the form of service behavior that satisfies the members. Members receive the main service and receive 
remuneration in accordance with the contribution given to the cooperative, both contributions that are material and non-material.

Figure 3. Triple Helix in Effectiveness of Participant

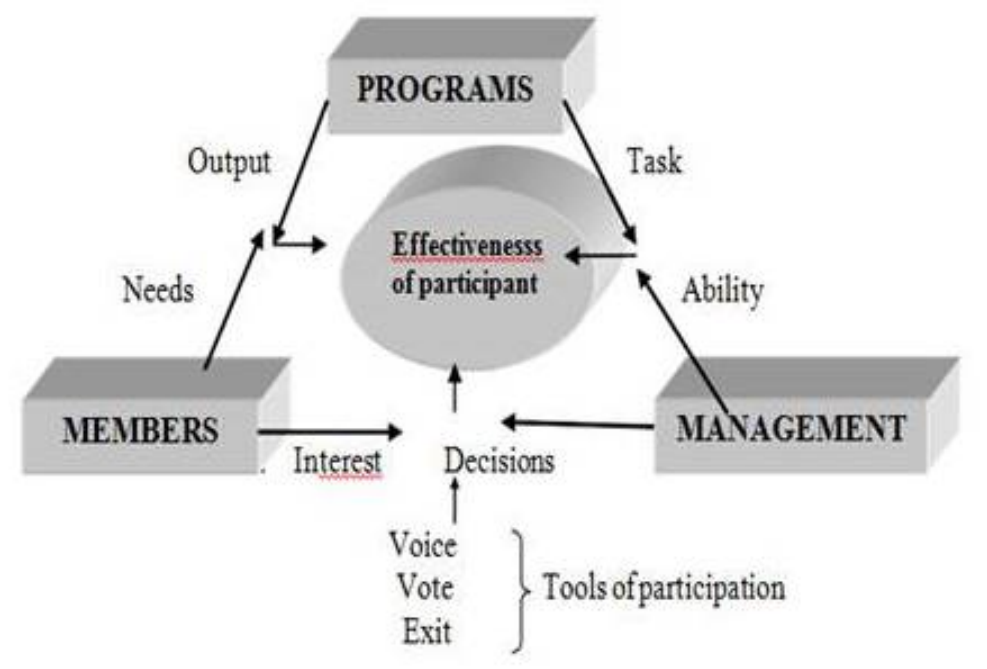

Cooperative member participation into three types, namely resource participation, decision making, and benefits. These three types of participation are related to each other. Members who do not benefit from cooperatives will not give up their resources. Likewise the cooperative will not provide benefits to its members if the concerned does not participate in making decisions [14]. Article 20 states that members have an obligation to participate in business activities organized by cooperatives [3].

The quality of participation of cooperative members is determined by the interaction between members, management, and the program. Participation of members in cooperatives will be achieved ideally if: There is a match between the interests of members and management decisions, There is a match between the needs of members and program output, There is a match between program tasks and management capabilities. Figure 2 and 3 shows the relationship between members, programs, and cooperative management.

Administrators in serving members should strive to: provide adequate rewards for those who provide capital to cooperatives, and guarantee the security of their investments, invest in the supply of goods and services in an efficient manner and are able to provide employment opportunities, provide information to members about things that are worth knowing as long as they do not disturb the security or efficiency and effectiveness of the cooperative business.

\section{Employee Support}

Cooperatives that are still relatively small, management of their business is still possible to be handled by the management, but in cooperatives that have a large scope of administration, administrators need personnel to manage their daily business, which is usually appointed by managers or employees.

The cooperative management can appoint managers who are authorized and authorized to manage the business. This article indicates that there are limited capabilities possessed by the management in managing cooperatives [3]. Appointment of a manager is based on improving the performance of cooperatives that experience an increase in the volume of business activities, but do not reduce the responsibility of the management. 
Cooperative employees are an integral part of efforts to provide services to members. Task of employees of cooperative business entities is to carry out daily corporate tasks in accordance with the authority delegated to each employee. The existence of cooperative employees as a result of cooperative companies has increased, so that the problems faced become complex. In this regard, the loyalty (support) of employees to the work of the management is absolutely necessary, because it helps the tasks of service to members and the community [22].

Managers should have the ability to empower employees so they can act as expected. Employees should be considered to have the knowledge and technology needed for them, and he must support the business of employees by removing barriers that prevent superior performance. For this statement, employees need to be given the freedom to innovate in completing their work. Managers who are honest and humble in assessing employee jobs can foster an atmosphere of conducive working relationships [10].

Managers must recognize and realize the importance of employees in cooperatives. The management should strive to: create a work and communication atmosphere that supports the development of cooperative relationships inspired by a mutual cooperation spirit, so that a sense of belonging, participation, sense of responsibility and encouragement for achievement grows, develop cooperative employees so that they grow into groups that are increasingly prosperous, effective and efficient, provide opportunities and encourage the growth of innovation, and productive creativity.

The position of cooperative employees as people who serve members or customers, then employees must have high integrity. Employees who have high integrity mean that they have the ability to realize what they say. Conversely, if you do not have integrity, he will only realize things that benefit him.

\section{CONCLUSION}

Cooperative organizations as institutions are in an environment that has different characteristics and characters. In general, there are seven different types of environments, namely: the legal and political environment, economic, social, ethical and cultural, defense and security, technology, and international. The environment directly affects the internal state of cooperative institutions [18]. The size of the influence received by the cooperative depends on the resilience of the cooperative itself.

Including the scope of the environment include social-economic conditions, education, politics, legal certainty, and culture. If the scope of politics, legal certainty, and culture are considered as given factors, the internal institutions of cooperatives are influenced by socio- economic factors and education [22].

Earlier emphasizes education, both formal and non-formal education. Educated cooperative members will have the knowledge and skills that can encourage the development of cooperatives [23]. Likewise who included educational factors as a minimum requirement for the growth of cooperatives [11]. The success or failure of a cooperative organization depends on the quality of its members [21].

The view that education and income are considered to have an influence on the development of cooperatives is reasonable because the existence of cooperatives is a manifestation of member participation, both contributive and incentive. The emergence of member participation is a result of the role of members, namely as owners and customers. Contributive participation 
needs to have adequate member education support. Likewise, with the participation of incentives, economic support is needed. Education and income correlate with member participation [30].

\section{NOVELTY}

There have been many studies on the performance and success of cooperatives using various variables, analytical methods, statistical approaches, and specific case studies in various parts of the world. However, this research is feasible and more interesting, because there are a series of development models descriptively. expectations in the future, quantitative experiments can be conducted further to get a comparison benchmark.

\section{References}

Anwar, C. Pengaruh Kemampuan Diri dan Kelengkapan Informasi Akuntansi Keuangan Terhadap Kinerja Manajemen Usaha KUD di Kotamadya Bandar Lampung. Tesis (terpublikasi). 1994. Bandung: PPS Universitas Padjadjaran Bandung.

Amini, A. M., \& Ramezani, M. Investigating the Success Factors of Poultry Growers' Cooperatives in Iran's Western Provinces. In World Applied Sciences Journal. 2008. 5(1): p. 81-87.

Anonymous. Law of the Republic Indonesia of Number: 25/1992 about Cooperatives. 1992. Bandung: UPTPenerbitan dan KKBM IKOPIN.

Falshaw, R. J., Glaister, K. W., \& Tatoglu, E. Evidence on formal strategic planning and Company performance. Management Decision. 2005. 44(1): p. 9-30.

Firman. Labour Flows in West Java: The Case of Housing Construction Worker in Bandung. 1985. Honolulu: EastWest Population Institut.

Hassan, A. Indonesian Cooperative Business Ethics Code. 1986. Jakarta: Ministry of Cooperatives of the Republic of Indonesia.

Hanel, A. Cooperative Organization. 1985. Bandung: Universitas Padjadjaran.

Henda, K. Ekonomi koperasi untuk perguruan tinggi. 2002. Jakarta: Fakultas Ekonomi, Universitas Indonesia.

Heryanto. Mekanisme Kerja Pengurus Koperasi Unit Desa Bejomu Lempake Samarinda. Tesis (terpublikasi). 1996. Yogyakarta: PPS IKIP a.

Mulyadi., \& Setyawan, J. Sistem Perencanaan dan Pengendalian Manajemen. 2001. Jakarta: Salemba Empat.

Münkner, H. H. Pengantar Hukum Koperasi. 1987. Bandung: Universitas Padjadjaran.

Partadiredja, A. Manajemen Koperasi. 1986. Jakarta: Bhratara Karya Aksara.

Pathak, R. D., \& Kumar, N. D. The key factors contributing to successful performance of cooperatives in Fiji for building a harmonious society. International Journal of Public Administration. 2008. 31(6): p. 690-706.

Ropke, J. Ekonomi Koperasi: Teori dan Manajemen. 2000. Jakarta: Salemba Empat.

Sushila, D. R., Nurizah, N., Mohd, S. A., Rafedah, J., \& Farahaini, M. H. Factors influencing the performance of cooperatives in Malaysia: A tentative framework. Malaysian Journal of Co-operative Management. 2009. 5: p. 4362.

Sushila, D. R., Nurizah, N., Mohd, S. A., Rafedah, J., \& Farahaini, M. H. Success factors of cooperatives in Malaysia: An exploratory investigation. Malaysian Journal of Co-operative Studies. 2010. 6: p. 1-24.

Sukamdiyo. Manajemen Koperasi. 1996. Jakarta: Erlangga.

Sukanto, R. Manajemen Koperasi. 1992. Yogyakarta: BPFE-Universitas Gadjah Mada.

Suratno. Keefektipan Pelatihan Akuntansi Koperasi. Tesis (terpublikasi). 1995. Yogyakarta: PPS IKIP.

Sukanto, T., \& Hani, T. H. Organisasi Perusahaan. 1994. Yogyakarta: BPFE

Swasono, S. E. Koperasi Dalam Orde Ekonomi Indonesia. 1985. Jakarta: UI-Press.

Suwandi, I. Koperasi Organisasi Ekonomi yang Berwatak Sosial. 1985. Jakarta: Bhratara Karya Aksara.

Syamsuri, S. A. Daya Hidup Koperasi dan Implikasinya Terhadap Kesejahteraan Anggota. Disertasi (terpublikasi). 1986. Bandung: FPS IKIP Bandung. 
Terry, G. R. The Principles of Management. 1972. Illinois: Richard D. Irwin Inc.

Unal, V. U., Guclusoy, H., \& Franquesa, R. A comparative study of success and failure of fishery cooperatives in the Aegean, Turkey. 2009. Journal of Applied Ichthyology. 25(4): p. 394-400.

University of Wisconsin Centre for Cooperatives. Report on Strategic Planning and Cooperatives Performance. 2010. Web site: http://www.uwcc.wisc.edu/info (access on December 10, 2019).

Wayan, B. Analisis Faktor Pribadi dan Kepuasan Kerja serta Dampaknya Terhadap Pegawai Pemerintah Daerah Tingkat II Propinsi Bali. Tesis (terpublikasi). 1999. Bandung: PPS Universitas Padjadjaran.

Wexley, K. N., \& Yukl, G. A. Perilaku Organisasi dan Psikologi Personalia. 1992. Bandung: Alumni.

Wirasasmita, Y. (Koperasi, Cooperative Effect (Dampak Koperasi) dan Kesejahteraan Anggota. Makalah. 2000. Bandung: Universitas Padjadjaran.

Zahri, C. Beberapa Faktor Yang Menentukan Keberhasilan Koperasi Unit Desa di Kabupaten Aceh Utara. Tesis (terpublikasi). 1993. Bandung: PPS Universitas Padjadjaran. 